Int. J. Dev. Biol. 55: 713-718

doi: $10.1387 /$ ijdb.113381ow

\title{
Signaling networks in cancer - an interview with Christian Gespach
}

\author{
OLIVIER DE WEVER* \\ Laboratory of Experimental Cancer Research, Ghent University Hospital, Ghent, Belgium
}

\begin{abstract}
The dynamic, innovative temperament of Christian Gespach is ideally suited to unraveling some aspects of the complex molecular networks connected with signal transduction, cancer progression and treatment. He is one of the pioneers who opened, in the early 1980s, new insights into the signaling mechanisms of G-protein coupled receptor (GPCR) activation, desensitization, internalisation and crosstalks. Twenty five years later and in collaboration with Gespach, IPSEN pharmaceuticals designed pan-inhibitors of GPCR signaling, targeting G $\alpha$ subunits in breast cancer progression and other epithelial cancers. Creativity is of vital importance to understand signal transduction pathways engaged in cancer cell motility, invasion and drug resistance. Christian Gespach has published more than 200 papers in cancer research, a true signal transduction tale.
\end{abstract}

KEY WORDS: interview, molecular network, GPCR, motility

Christian Gespach started his lifetime dedication to Science and Medical Research as a Pierre and Marie Curie student in 1967 (University Paris VI, France). During University training he worked in a full time position at the French National Education Colleges in Paris and Créteil Academy (1968-1976). He subsequently performed his graduate studies in Hospital Saint-Antoine (INSERM U55 laboratory), where he was involved in projects aiming at elucidating the role of glucose, incretins and neuropeptides in the biosynthesis and secretion of pancreatic hormones (1975-1977). As a PhD graduate, he joined the laboratory of Dr. Jean-Pierre Abita at INSERM U204 (1979-1987), Hospital Saint-Louis (signal transduction in normal and leukemic hematopoietic cells) to work on histamine $\mathrm{H} 2$ receptors, neutrophil chemotaxis and differentiation of leukemic cells by retinoic acid, vitamine D3 and bile acids (Zimber et al., 2000). In 1979, he obtained a staff position at INSERM in Paris, where he continued to work on signal transduction in normal and cancerous digestive epithelial cells and leukemic cells (State Doctorate in Sciences, 1986).

My first contact with Christian Gespach was via a telephone conference in 2001. During this period, we had several interactions concerning the role of myofibroblasts in colon cancer invasion. Proof of the fruitful discussions was the publication of the work in FASEB Journal and Journal of Cell Science (De Wever et al., 2004a, De Wever et al., 2004b). After my PhD in 2004, I was fortunate to organize multiple long term and short term yearly visits to the Gespach lab. Paris is only $300 \mathrm{~km}$ away from Ghent and luckily we have a direct fast train connection. A two hour trip brings you from Ghent in Paris Nord train station. My first stay covered about 8 weeks in late May till early July of 2004. I stayed in a picturesque house in Périgny-sur-Yerres, a suburb $25 \mathrm{~km}$ to the south of Paris. One of the crazy experiments during those days was a bicycle trip during rush hour from Périgny to the host lab, located in the center of Paris. The Gespach lab had a driving scientific atmosphere with multiple successful young lab members such as Samir Attoub, Quang-Dé Nguyen, Sylvie Rodrigues, Nathalie Le Floch, Christelle Rodrigue and Christine Rivat. I was honoured to perform experiments with so many creative minds educated by Christian Gespach. This visit formed a solid basis for multiple future publications and collaborative efforts.

In December, 2010 Christian Gespach was invited to the Ghent laboratory of Experimental Cancer Research to discuss recent collaborative data. The day started with discussing a future strategy about the NM23 metastasis suppressor. This project was engaged under mutual interactions with Dr. Mathieu Boissan and Dr. MarieLise Lacombe in Hospital Saint-Antoine, INSERM U938 showing that the metastasis suppressor $\mathrm{NM} 23 \mathrm{H} 1$ is involved in the maintenance of E-cadherin-based adherens junctions and control of epithelial cancer cell scattering and adhesion in primary tumors (Boissan et al., 2010). We continued the discussion about the cross-signaling between bone marrow-derived mesenchymal stem cells and colon cancer cells. Only at the end of the day I managed to squeeze in a few of my questions!

Abbreviations used in this paper: GPCR, G-protein coupled receptor.

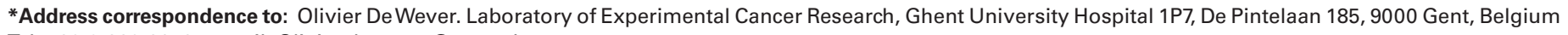
Tel: +32-9-332-3073. e-mail: Olivier.dewever@ugent.be
}

Final, author-corrected PDF published online: 29 November 2011

ISSN: Online 1696-3547, Print 0214-6282

(C) 2011 UBC Press

Printed in Spain 


\section{Did your family have a strong scientific tradition?}

My family was not involved in practical or experimental medicine but was mainly working in accounting expertise and commercial banking.

\section{When did you enter into the field of cell signaling?}

I was scientifically born as a researcher in the laboratory of Dr. Gabriel Rosselin (INSERM U55) working on Diabetes and Digestive Diseases (membrane receptors, signal transduction and cyclic nucleotides cAMP /cGMP).

Christian Gespach is one of the pioneers who opened, in the early 1980s, new insights in the signaling mechanisms of Gprotein coupled receptors (GPCRs) activation, desensitization, internalisation and crosstalks (VIP and histamine $\mathrm{H} 2$ receptor regulation by somatostatin).

As shown in Fig. 1, the G-proteins $\mathrm{G} \alpha$ and $\mathrm{G} \beta \gamma$ signaling systems downstream GPCR cycle between ligand activated $\mathrm{G} \alpha$-GTP $+\mathrm{G} \beta \gamma$ subunits and return to the G $\alpha$-GDP /G $\beta \gamma$ heterotrimeric, inactivated state. The GTP-bound activated state of $\mathrm{G} \alpha$ proteins can be mimicked by aluminium fluoride (AIF4-) and the nonhydrolyzable GTP analogues GTP- $\gamma$ S and GDP-NHP (Fig. 2).

Relations of GPCR signaling with oncogenic pathways and functional defects associated with the progression of epithelial cancers were analyzed by Gespach et al., in normal, immortalized and transformed epithelial cells of the colon, stomach and breast (Gespach et al., 1980, Gespach et al., 1981a, Gespach et al., 1981b). Twenty five years later and in collaboration with Gespach, IPSEN pharmaceuticals designed pan-inhibitors of GPCR signaling targeting G $\alpha$ subunits in the MCF-7 breast cancer cell line and the invasive growth of epithelial cancer cells and tumors (Ayoub et al., 2009, Prevost et al., 2006) (Fig. 3). Many GPRC signals are connected with critical dysfunctions inherent to leukocyte and epithelial cell chemotaxis and oncogenesis. First attempts to control cancer progression by targeting a given GPCR were unsuccessful because of the multifactorial nature and partial redundancy of the genetic and molecular defects driving neoplasia. Recently, the therapeutic anti-cancer potential of these small molecule signaling inhibitors downstream GPCR has been documented by other groups targeting $\mathrm{G} \beta \gamma$ subunits. GPCR and their signal transduction systems are involved in normal development, various physiopathological states and are now considered as canonical oncogenic pathways in breast cancers and clinical tumors (Fig. 4). At the end of the nineties, Gespach laboratories have made significant advances in molecular and clinical oncology of epithelial tumors in breast, gastrointestinal tract and urogenital systems. For example, Dr. Gespach contributed to the elucidation of several mechanisms involved in gene expression (TCF/LEF1- $\beta$-catenin and c-Jun/AP-1 synergy, STAT-3 signaling), cancer cell differentiation, invasive growth, tumor angiogenesis, metastasis and chemoresistance. This was accomplished at the

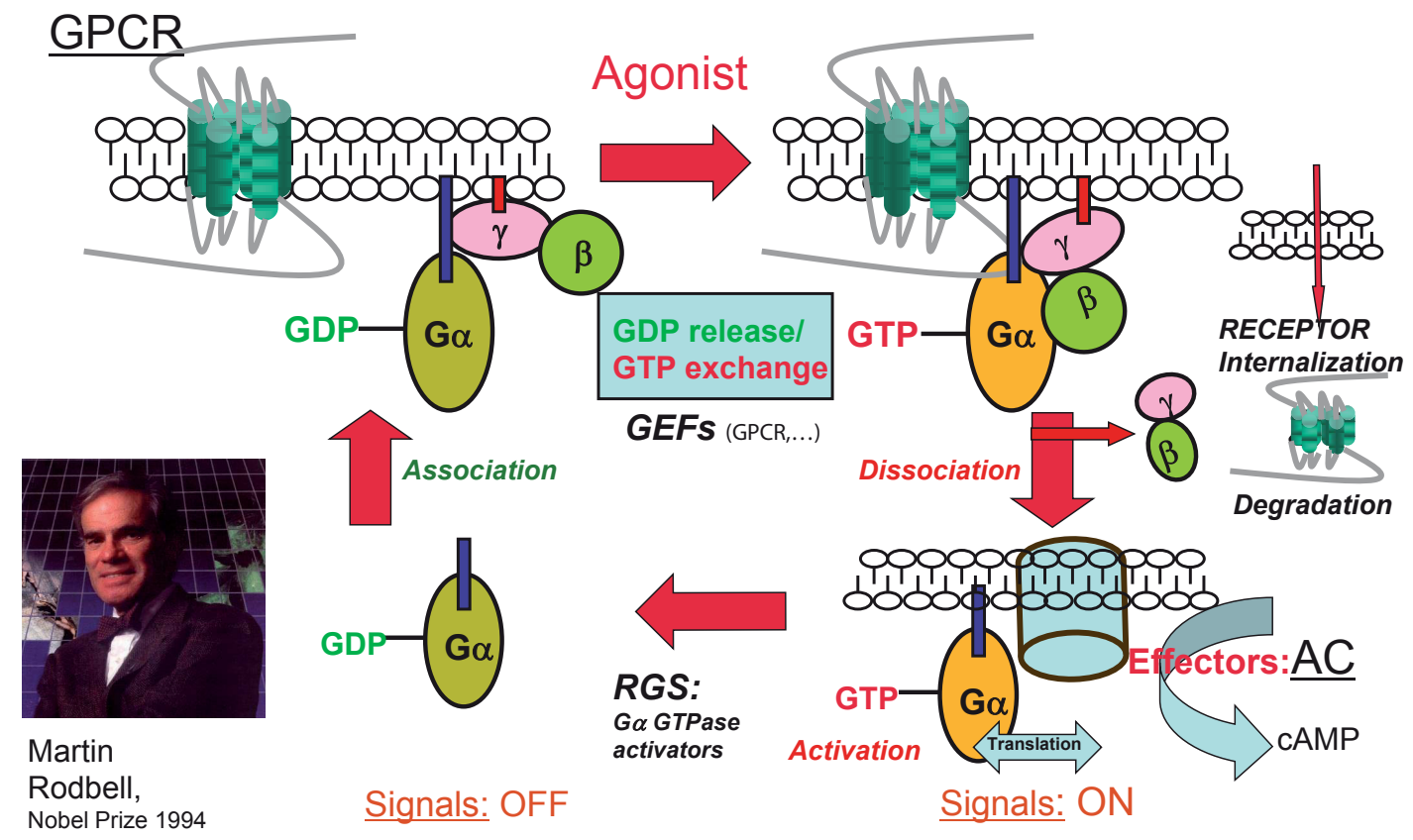

Fig. 1. G-protein coupled receptor (GPCR) signaling and the G $\alpha$-GDP /G $\alpha$-GTP cycle of the heterotrimeric G-proteins (hGP). The G-protein concept of GTPases transducers cycling from GTP/GDP intermediates originates from the original discovery of Martin Rodbell and Alfred Gilman (Nobel prize laureates, 1994). Both heterotrimeric G-proteins (hGP) downstream GPCR and Ras superfamily small G-proteins downstream growth factor receptors are playing crucial roles in normal development and malignant transformation. Latent G $\alpha / \beta \gamma$ heterotrimeric G-proteins are membrane-associated under

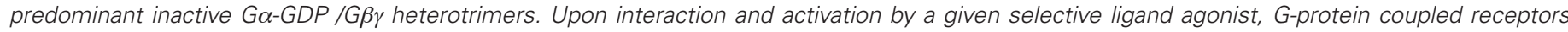
(GPCR) promote GPCR- hGP interaction and the GDP /GTP exchange at Ga subunits through G-protein exchange factors GEFs, leading to decreased

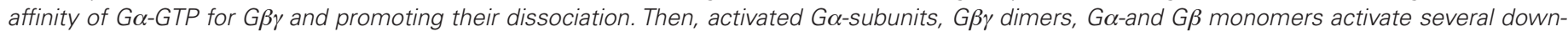

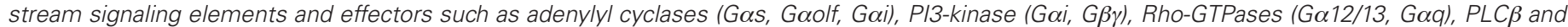

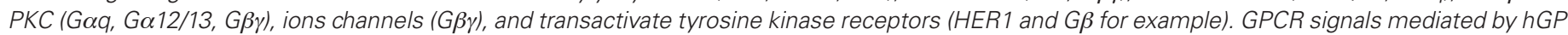
are interrupted or reinitialized by several mechanisms including: i) GPCR phosphorylation by GPCR kinases; ii) Receptor internalization, degradation

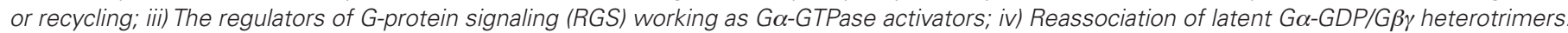




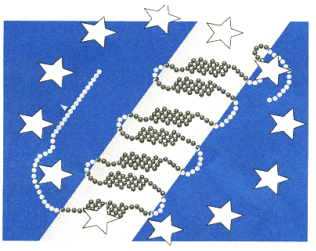

1 ${ }^{\text {ST }}$ INTERNATIONAL SYMPOSIUM ON VIP, PACAP \& RELATED REGULATORY PEPTIDES FROM MOLECULAR BIOLOGY TO CLINICAL APPLICATIONS
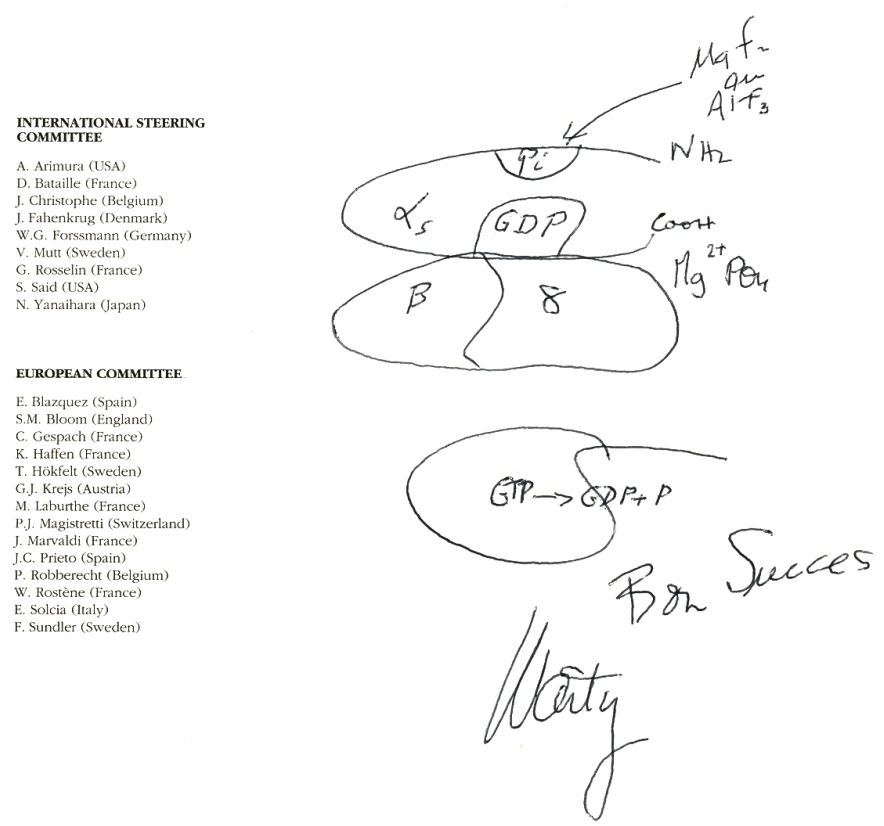

President :

Gabriel ROSSELIN

INSERM U. 55

EET DIABETH

Centre de Recherches Paris Saint Antoine

184, rue du Faubourg St Antoine
75571 PARIS CEDEX 12, FRANCE

level of the retinoblastoma proteins $p R b 1$ and $\mathrm{pRb} 2$, src, Wnt receptors Frizzled, CXCR4 /MIF axis, thrombin PAR-1 and their signaling commutators (RhoA/ RhoD, the NO/ cGMP axis), the Gep oncogenes $\mathrm{G} \alpha 12 / 13$, the $\mathrm{G \alpha i}$ subunits family including the and Gip2 oncogene Goi2, G $\beta \gamma$ and Goolf). The INSERM U482 and U673 Teams (Fig. 5) contributed to major advances on oncogenic pathways controlled by receptor and nonreceptor tyrosine and serine/threonine kinases TGF $\beta$, PKC $\alpha$, c-kit, leptin, VEGF/ semaphorin family and neurotensin), Rho-like small GTPases, trefoil factors family TFF and their connections with src and EGFR, netrin and deleted in colon cancer (DCC dependance receptor and adenosine $\mathrm{A} 2 \mathrm{~b}$ co-receptor), and functional responses to the estrogen receptor $\alpha(E R \alpha)$-dependent nuclear transcription factor and repressor WISP-2 and its implication in epithelialmesenchymal transition (EMT). A significant account of research directed by Gespach was focused on immortalization

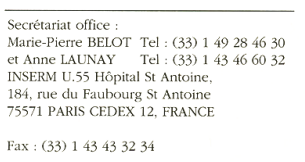

Fax : (33) 14343234
Fig. 2 (Left).Aluminium FluorideAIF4-as a GPCR-independent activator of G-proteins by mimicking the $\mathbf{G} \alpha$-GTP transition-activated state of G $\alpha$-proteins (G $\alpha$-GDP.AIF4-). Model of Martin Rodbell dedicated to Christian GESPACH ("Bon Succès») during the 1st International Symposium on VIP, PACAP and related regulatory peptides in Strasbourg (Bischenberg, 1993).

and transformation of human colon and breast and epithelial cells in order to mimick and characterize genetic, molecular and functional mechanisms at the adenoma-adenoma transition: SV40 Large T, Adenovirus 2 E1A, Ras /TGF $\beta$, Src and Polyoma middle Toncogenes (Berthon et al., 1992, Chastre et al., 1991, Emami et al., 1989, Empereur et al., 1997). This strategy was also applied to other genetic diseases such as Myasthenia gravis and Cystic Fibrosis (Chastre et al., 1991, Lemnaouar et al., 1993, Marie et al., 1999). Preclinical studies supporting the therapeutic role of signaling inhibitors and oxaliplatin combined with 5-FU and folinic acid /leucovorin or irinotecan were the basis of current chemotherapy in colorectal cancer, the FOLFOX and FOLFIRI regimens (Andre et al., 2004, Raymond et al., 1997). INSERM U482 was the first laboratory to clone the alternative spliced form of Rac1 encoding the constitutively activated form of this GTPase named Rac1b (Jordan et al., 1999). This important discovery was based on the novel hypothesis of Dr. Gespach that molecular alterations might target the Rho-like small GTPases, as described for Ki-ras mutations in a vast majority of epithelial cancers. The hype started in 2005 when the Bissell group published in Nature a crucial role of Rac1b in matrix metalloproteinase-3 induced EMT and invasion in breast cancer cells (Radisky et al., 2005). As recently reviewed by $\mathrm{C}$. Gespach, clinical breast cancers and several malignant epithelial tumors display EMT signatures and markers with prognosis significance for recurrence, metastasis, overall survival and therapeutic resistances (Sabbah et al., 2008). Christian Gespach was invited as speaker and chairman in more than 40 international

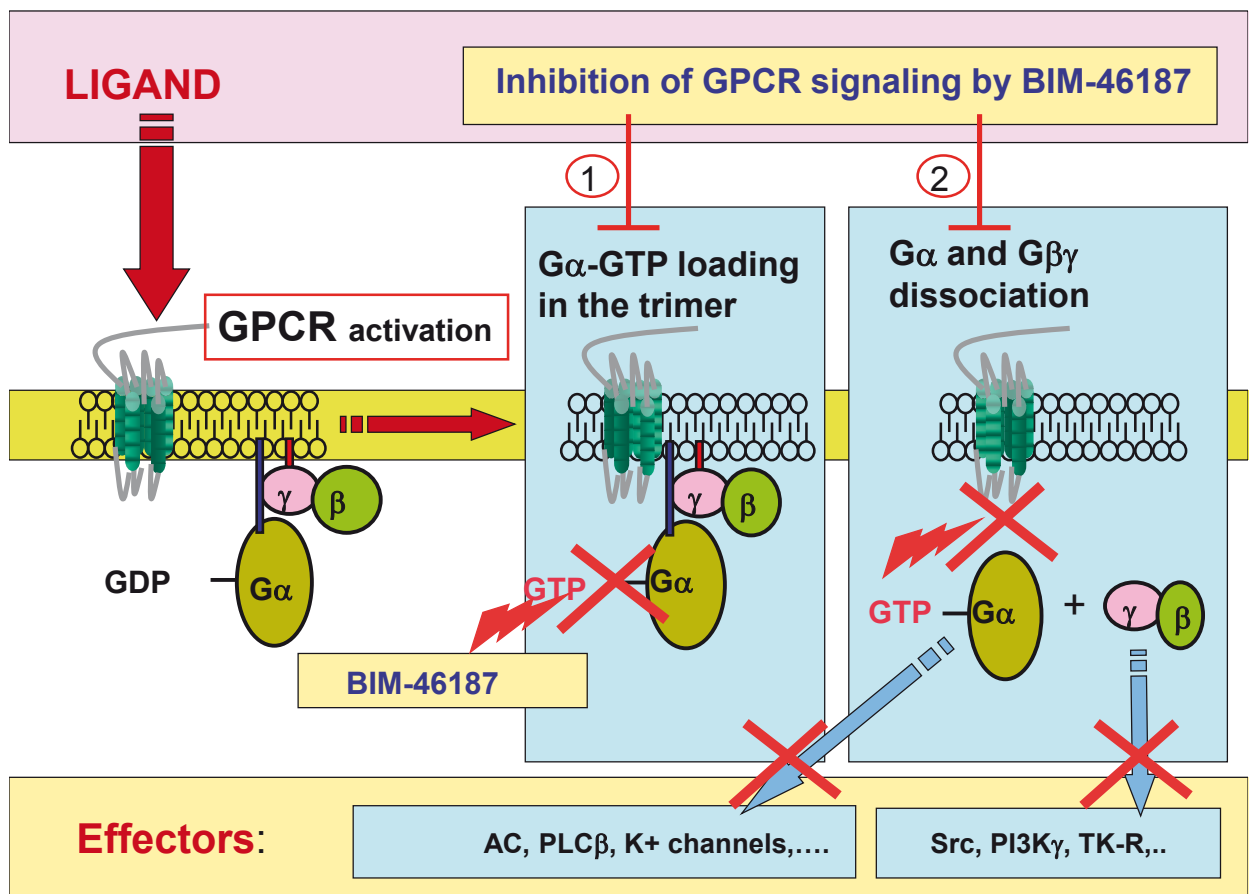

Fig. 3. BIM-46187 is a GPCR signaling inhibitor targeting both Ga protein activation and G $\boldsymbol{\beta} \gamma$ dissociation. 


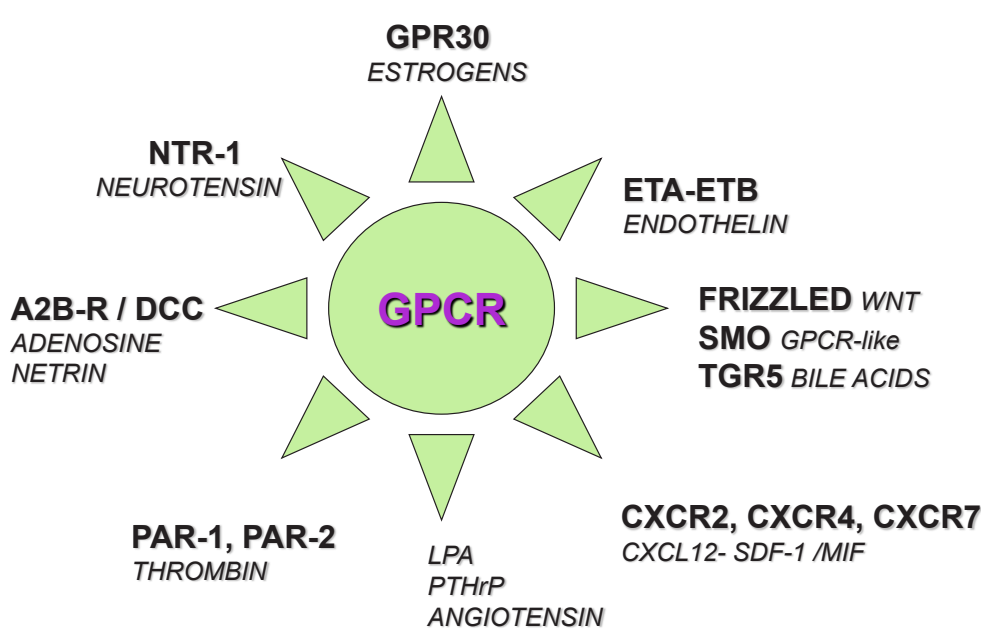

Proliferation, Wound Healing, Stem cell maintenance, Inflammation, Invasion, EMT, Survival, Angiogenesis, Metastasis, Drug resistance

Fig. 4. GPCR agonists in development, neoplasia and breast cancer.

meetings, conferences and seminars in Europe, USA, Canada, Venezuela, United Arab Emirates, China and Japan (Fig. 6).

Tumors and their metastatic niches are complex organs consisting of genetically reprogrammed cancer cells and the tumor stroma (from Greek translated as "bed"). This tumor stroma is also reciprocally "transformed" by cancer cells and consists of complex networks of extracellular matrix (ECM) molecules involved at several interfaces with fibroblasts, adipocytes, mesenchymal stem cells, the vascular and immune systems. Tumor-associated fibroblasts that express $\alpha$-smooth muscle actin are referred to as myofibroblasts. Myofibroblasts are factories producing multiple growth factors, ECM proteins and proteases to support cancer invasion. Where do we stand today with the clinical applications of this concept?

Several signals from the literature highlight the critical importance of the molecular and cellular crosstalks between cancer cells and their immediate and distant environment, respectively the tumor stroma, mesenchymal stem cells in bone marrow and other tissues,

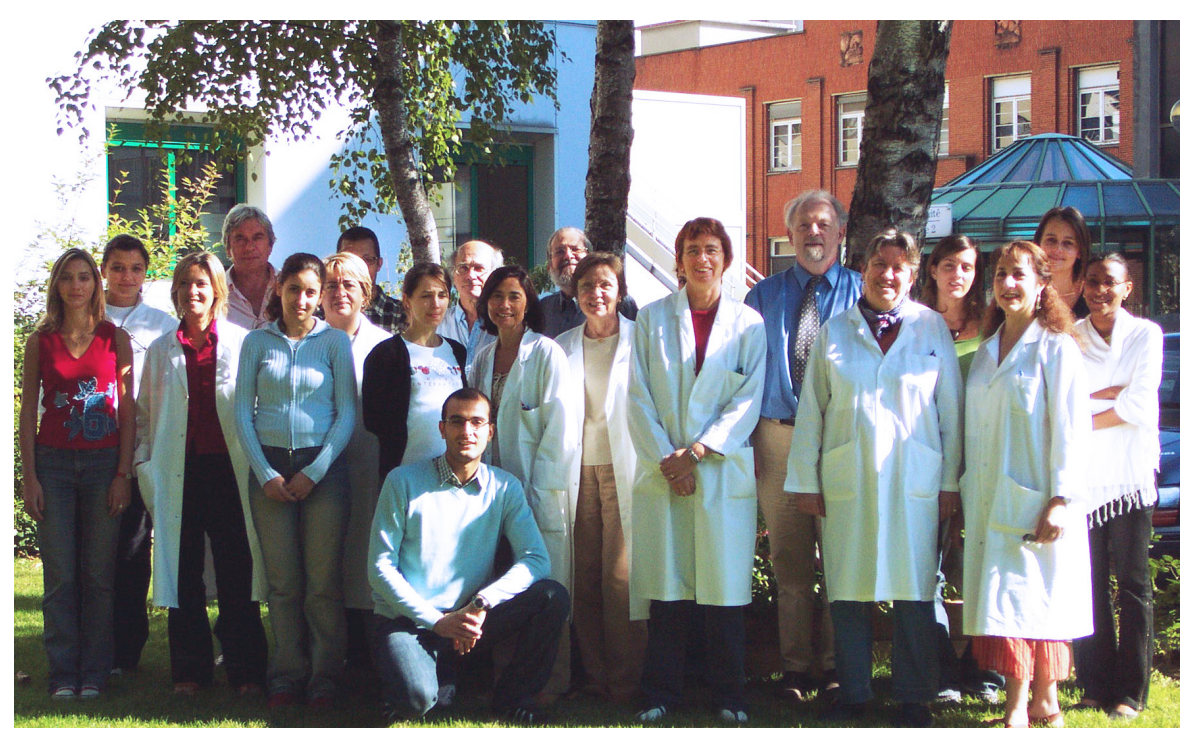

and also from metastatic sites, according to the self-seeding and trafficking theory of the Massague and Weinberg groups (reviewed in Gespach, 2010). It is therefore apparent that the cancer cell-stroma connections are invoved in several steps of the neoplastic conversion, including cancer initiation, promotion and progression. Thus, the response of a given malignant tumor to chemotherapy and radiation should be considered in view of the respective roles and sensitivity of these compartments to a given treatment. Drug resistances and cancer cell survival mechanisms originate from these questions. A better knowledge of these mechanisms and therapeutic disruption of their fatal consequence appears to be one of the major challenges for the next 10 years.

A recent $P$ ubmed search revealed less than 400 citations for Rab and cancer. Although belonging to the Ras family of small GTPases, RabGTPases are unexpected players in the cancer signaling field? This contrasts starkly with the founding members of the Ras superfamily small GTPases (H-Ras, Ki-Ras and N-Ras) which are prototypic oncogenes with more than $\mathbf{2 0 . 0 0 0}$ hits in Pubmed.

I think that it is not surprising that regulated secretory RabGTPases are involved in cancer progression because released products from cancer cells and tumor stroma cells are playing major roles on autocrine, juxtacrine and paracrine regulations and transforming functions in cancer cells, adjacent tumor stroma cells, and systemic regulations of distant metastasis by cancer cell homing and growth. We have greatly contributed to this concept to identify critical secreted factors from cancer cells and tumor stromal cells by using conditioned culture medium and co-culture systems (De Wever et al., 2010, Hendrix et al., 2010).

The Laboratory of Experimental Cancer Research in Ghent and your INSERM group in Paris have a long and successful collaborative tradition. The year 2010 has been very successful with multiple high-impact joined publications and several reciprocal visits in Ghent and Paris. The joint research visits are funded by the Egide and Tournesol program fueling collaborative efforts between the Flemish community and France. What do you feel about the future?

I think that the French and Belgium Research Institutes for Life Sciences should organize and intensify more tightly collaborations supported by a common Institute of Life Science and Technology devoted to Cancer Research and Treatment. A synergy based on science-based Academic Institutions and Pharmaceutical Industry, but not on administration -based in-

Fig. 5. Part of the staff in INSERM U673 (Molecular and Clinical Oncology) made up of 55-65 members (Hospital Saint-Antoine, 2006). Heads and main contributors of the Teams: Drs. A. Atfi, $L$. Levy and C. Prunier (TGF $\beta$ and cancer progression): Drs. P. Forgez, C. Gespach, S. Attoub, E. Chastre, S Emami, G. Redeuilh, M. Sabbah (Invasive growth, Angiogenesis in Colon and breast cancers); Pr. A. de Gramont, Drs. A. Larsen and Prs. T. André, S. Faivre and E. Raymond (Preclinical studies and Clinical trials in colorectal cancer). 


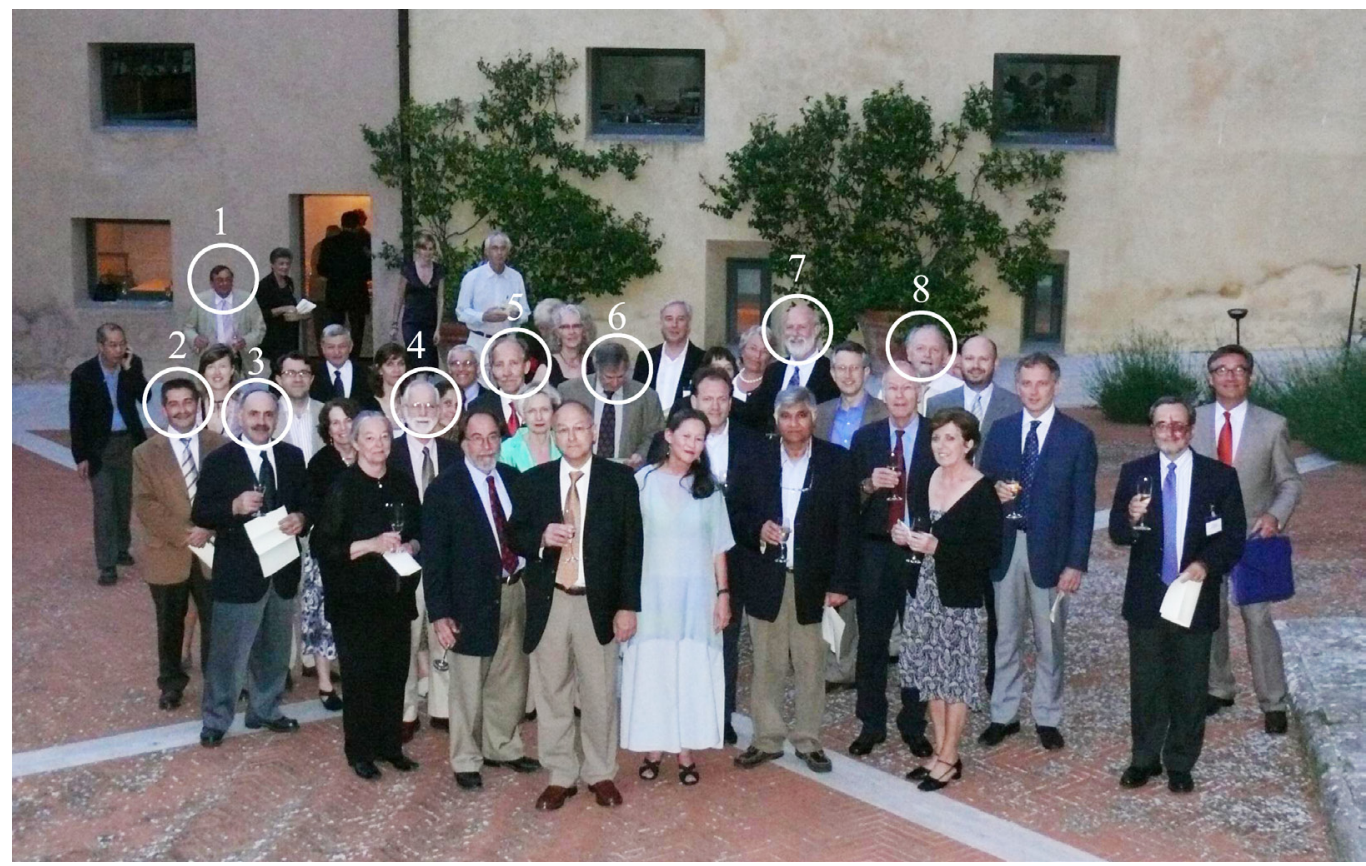

Fig. 6. The Metastasis and Invasion Seminar organized by the IPSEN Foundation in Spineto, May 2023, 2007 (Tuscany, Italy). Scientists working on Christian Gespach most closely related fields included:, , Daniel Louvard (number 1), Philippe Clézardin (number 2), RobertWeinberg (number 3), Michael Bishop (number 4), Kari Alitalo (number 5), Joan Massagué (number 6), Robert Hynes (number 7) and Christian Gespach (number 8). I apologize for not mentioning the other distinguished international scientists participating to the meeting.

stitutions, will offer a comprehensive project to promote significant advances in this field.

\section{What is the publication that you are the most proud of?}

Emami S, Le Floch N, Bruyneel E, Thim L, May F, Westley B, Rio MC, Mareel M, and Gespach C. Induction of scattering and cellular invasion by trefoil peptides in src- and RhoA- transformed kidney and colonic epithelial cells. The FASEB Journal. 15: 351361 (2001, Page cover of the Journal) (Emami et al., 2001). This publication was the leading discovery of several reports from our laboratory and several international research institutions on the transforming roles of trefoil factors (TFFs) in epithelial cancers. I think that this report opened new avenues for cancer research and treatment (reviewed in (Emami et al., 2004). Most importanly, Gespach clarified the dual roles of TFFs and their therapeutic potential on wound healing, mucosal repair, transient inflammatory situations and tumorigenesis. In the stomach, TFF1 is bona fide a gastric tumor suppressor gene lost by epigenetic silencing. Consistently, TFF1 /pS2 is a limiting factor against the erosion of the gastric epithelial cell surface and counteracts inflammatory situations and cancer promotion. In contrast, in the mucosa of the lower digestive tract and colon, TFFs are found to be overexpressed and display pejorative functions during these chronic pathological states. In breast cancer, TFF1 expression is linked to a favorable prognosis for patient survival, butthis beneficial situation is linked to the differentiated -type, ER- $\alpha$-positive state of breast cancers that have a favorable prognosis because of their sensitivity to classical, efficient targeted hormone therapy (reviewed in Gespach, 2008).

\section{References}

ANDRE, T., BONI, C., MOUNEDJI-BOUDIAF, L., NAVARRO, M., TABERNERO, J., HICKISH, T., TOPHAM, C., ZANINELLI, M., CLINGAN, P., BRIDGEWATER, J. et al., (2004). Oxaliplatin, fluorouracil, and leucovorin as adjuvant treatment for colon cancer. N Engl J Med 350: 2343-2351.

AYOUB, M.A., DAMIAN, M., GESPACH, C., FERRANDIS, E., LAVERGNE, O., DE
WEVER, O., BANERES, J.L., PIN, J.P. and PREVOST, G.P. (2009). Inhibition of heterotrimeric $G$ protein signaling by a small molecule acting on Galpha subunit. J Biol Chem 284: 29136-29145.

BERTHON, P., GOUBIN, G., DUTRILLAUX, B., DEGEORGES, A., FAILLE, A., GESPACH, C. and CALVO, F. (1992). Single-steep transformation of human breast epithelial cells by SV40 large T oncogene. Int $J$ Cancer 52: 92-97.

BOISSAN, M., DE WEVER, O., LIZARRAGA, F., WENDUM, D., POINCLOUX, R., CHIGNARD, N., DESBOIS-MOUTHON, C., DUFOUR, S., NAWROCKI-RABY, B., BIREMBAUT, P. et al., (2010). Implication of metastasis suppressor NM23-H1 in maintaining adherens junctions and limiting the invasive potential of human cancer cells. Cancer Res 70: 7710-7722.

CHASTRE, E., DI GIOIA, Y., BARBRY, P., SIMON-BOUY, B., MORNET, E., FANEN, P., CHAMPIGNY, G., EMAMI, S. and GESPACH, C. (1991). Functional insertion of the SV40 large Toncogene in cystic fibrosis intestinal epithelium. Characterization of CFI-3 cells. J Biol Chem 266: 21239-21246.

DE WEVER, O., HENDRIX, A., DE BOECK, A., WESTBROEK, W., BRAEMS, G., EMAMI, S., SABBAH, M., GESPACH, C. and BRACKE, M. (2010). Modeling and quantification of cancer cell invasion through collagen type I matrices. Int $J$ Dev Biol 54: 887-896.

DE WEVER, O., NGUYEN, Q.D., VAN HOORDE, L., BRACKE, M., BRUYNEEL, E., GESPACH, C. and MAREEL, M. (2004a). Tenascin-C and SF/HGF produced by myofibroblasts in vitro provide convergent pro-invasive signals to human colon cancer cells through RhoA and Rac. FASEB J 18: 1016-1018.

DE WEVER, O., WESTBROEK, W., VERLOES, A., BLOEMEN, N., BRACKE, M., GESPACH, C., BRUYNEEL, E. and MAREEL, M. (2004b). Critical role of N-cadherin in myofibroblast invasion and migration in vitro stimulated by colon-cancer-cellderived TGF-beta or wounding. J Cell Sci 117: 4691-4703.

EMAMI, S., LE FLOCH, N., BRUYNEEL, E., THIM, L., MAY, F., WESTLEY, B., RIO, M., MAREEL, M. and GESPACH, C. (2001). Induction of scattering and cellular invasion by trefoil peptides in src- and RhoA-transformed kidney and colonic epithelial cells. FASEB J 15: 351-361.

EMAMI, S., MIR, L., GESPACH, C. and ROSSELIN, G. (1989). Transfection of fetal rat intestinal epithelial cells by viral oncogenes: establishment and characterization of the E1A-immortalized SLC-11 cell line. Proc Natl Acad Sci USA 86: 3194-3198.

EMAMI, S., RODRIGUES, S., RODRIGUE, C.M., LE FLOCH, N., RIVAT, C., ATTOUB, S., BRUYNEEL, E. and GESPACH, C. (2004). Trefoil factor family (TFF) peptides and cancer progression. Peptides 25: 885-898.

EMPEREUR, S., DJELLOUL, S., DI GIOIA, Y., BRUYNEEL, E., MAREEL, M., VAN HENGEL, J., VAN ROY, F., COMOGLIO, P., COURTNEIDGE, S., PARASKEVA C. etal., (1997). Progression of familial adenomatous polyposis (FAP) colonic cells 


\section{O.De Wever}

after transfer of the src or polyoma middle $\mathrm{T}$ oncogenes: cooperation between src and HGF/Met in invasion. Br J Cancer 75: 241-250.

GESPACH, C. (2008). Trefoil Factors in health and cancer disease.. In Encyclopedia of Cancer, (ed. SCHWAB, M.). Springer.

GESPACH, C. (2010). Stem cells and colon cancer: the questionable cancer stem cell hypothesis. Gastroenterol Clin Biol 34: 653-661.

GESPACH, C., BATAILLE, D., DUPONT, C., ROSSELIN, G., WUNSCH, E. and JAEGER, E. (1980). Evidence for a cyclic AMP system highly sensitive to secretin in gastric glands isolated from the rat fundus and antrum. Biochim Biophys Acta 630: 433-441.

GESPACH, C., BATAILLE, D., VAUCLIN, N., ROSSELIN, G., MORODER, L. and WUNSCH, E. (1981a). Secretin binding sites coupled with adenylate cyclase in rat fundic membranes. Peptides 2 Suppl 2: 247-251.

GESPACH, C., DUPONT, C. and ROSSELIN, G. (1981b). Action of histamine and vasoactive intestinal peptide (VIP) on cyclic AMP in gastric glands isolated from human fetal stomach. Experientia 37: 866-867.

HENDRIX, A., MAYNARD, D., PAUWELS, P., BRAEMS, G., DENYS, H., VAN DEN BROECKE, R., LAMBERT, J., VAN BELLE, S., COCQUYT, V., GESPACH, C. et al., (2010). Effect of the secretory small GTPase Rab27B on breast cancer growth, invasion, and metastasis. J Natl Cancer Inst 102: 866-880.

JORDAN, P., BRAZAO, R., BOAVIDA, M.G., GESPACH, C. and CHASTRE, E. (1999). Cloning of a novel human Rac1b splice variant with increased expression in colorectal tumors. Oncogene 18: 6835-6839.

LEMNAOUAR, M., CHASTRE, E., PAUL, A., MERGEY, M., VEISSIERE, D., CHERQUI, G., BARBRY, P., SIMON-BOUY, B., FANEN, P., GESPACH, C. et al., (1993). Oncogene-mediated propagation of tracheal epithelial cells from two cystic fibrosis fetuses with different mutations. Characterization of CFT-1 and CFT-2 cells in culture. Eur J Clin Invest 23: 151-160.

MARIE, J., WAKKACH, A., COUDRAY, A., CHASTRE, E., BERRIH-AKNIN, S. and GESPACH, C. (1999). Functional expression of receptors for calcitonin generelated peptide, calcitonin, and vasoactive intestinal peptide in the human thymus and thymomas from myasthenia gravis patients. J Immunol 162: 2103-2112.

PREVOST, G.P., LONCHAMPT, M.O., HOLBECK, S., ATTOUB, S., ZAHAREVITZ, D., ALLEY, M., WRIGHT, J., BREZAK, M.C., COULOMB, H., SAVOLA, A. et al., (2006). Anticancer activity of BIM-46174, a new inhibitor of the heterotrimeric Galpha/Gbetagamma protein complex. Cancer Res 66: 9227-9234.

RADISKY, D.C., LEVY, D.D., LITTLEPAGE, L.E., LIU, H., NELSON, C.M., FATA, J.E., LEAKE, D., GODDEN, E.L., ALBERTSON, D.G., NIETO, M.A. et al., (2005) Rac1b and reactive oxygen species mediate MMP-3-induced EMT and genomic instability. Nature 436: 123-127.

RAYMOND, E., BUQUET-FAGOT, C., DJELLOUL, S., MESTER, J., CVITKOVIC, E., ALLAIN, P., LOUVET, C. and GESPACH, C. (1997). Antitumor activity of oxaliplatin in combination with 5-fluorouracil and the thymidylate synthase inhibitor AG337 in human colon, breast and ovarian cancers. Anticancer Drugs 8: 876-885.

SABBAH, M., EMAMI, S., REDEUILH, G., JULIEN, S., PREVOST, G., ZIMBER, A., OUELAA, R., BRACKE, M., DE WEVER, O. and GESPACH, C. (2008). Molecular signature and therapeutic perspective of the epithelial-to-mesenchymal transitions in epithelial cancers. Drug Resist Updat 11: 123-151.

ZIMBER, A., CHEDEVILLE, A., ABITA, J.P., BARBU, V. and GESPACH, C. (2000). Functional interactions between bile acids, all-trans retinoic acid, and 1,25-dihydroxy-vitamin D3 on monocytic differentiation and myeloblastin gene downregulation in HL60 and THP-1 human leukemia cells. Cancer Res 60: 672-678. 


\section{Further Related Reading, published previously in the Int. J. Dev. Biol.}

Fibronectin and tenascin-C: accomplices in vascular morphogenesis during development and tumor growth Ellen Van Obberghen-Schilling, Richard P. Tucker, Falk Saupe, Isabelle Gasser, Botond Cseh, Gertraud Orend Int. J. Dev. Biol. (2011) 511 - 525 (doi: 10.1387/ijdb.103243eo)

Epithelial-Mesenchymal Transitions in development and disease: old views and new perspectives M. Angela Nieto

Int. J. Dev. Biol. (2009) 53: 1541-1547

Cadherin-mediated cell-cell adhesion and tissue segregation in relation to malignancy Ramsey A. Foty and Malcolm S. Steinberg

Int. J. Dev. Biol. (2004) 48: 397-409

The stroma reaction myofibroblast: a key player in the control of tumor cell behavior Alexis Desmoulière, Christelle Guyot and Giulio Gabbiani Int. J. Dev. Biol. (2004) 48: 509-517

Analysis of tenascin mRNA expression in the murine mammary gland from embryogenesis to carcinogenesis: an in situ hybridization study

I Kalembey, T Yoshida, K Iriyama and T Sakakura

Int. J. Dev. Biol. (1997) 41: 569-573

$$
5 \text { yr ISI Impact Factor }(2010)=2.961
$$

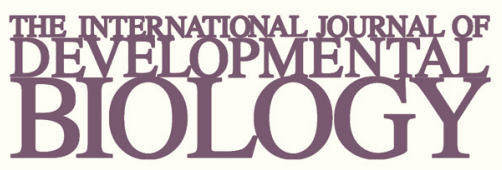

Volume 54 Nos. 6/7
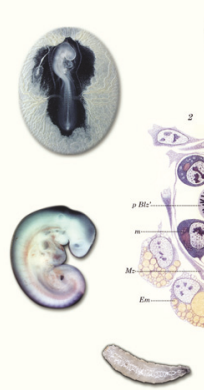

Developmental Hematopoiesis
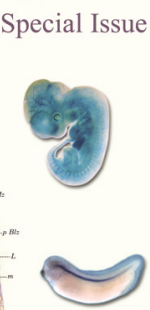

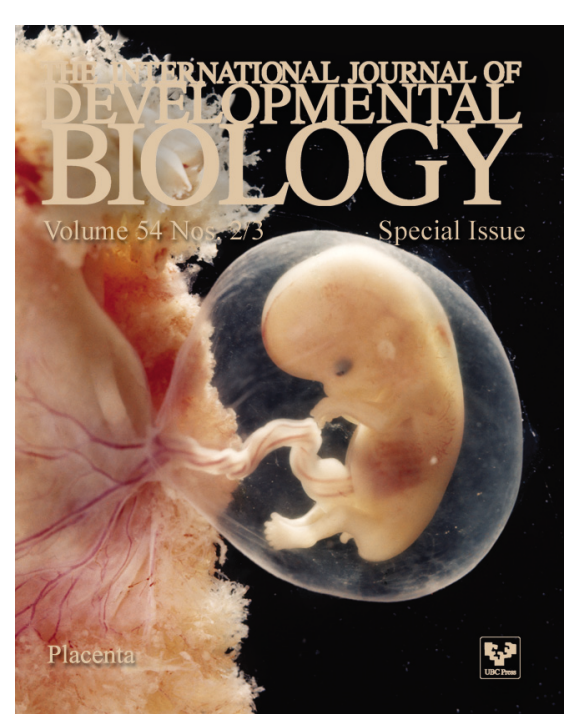

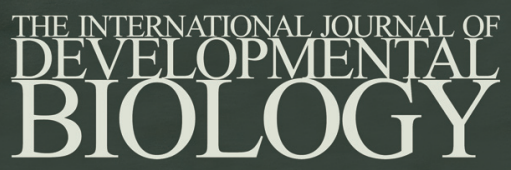

Volume 55 Nos. 4/5

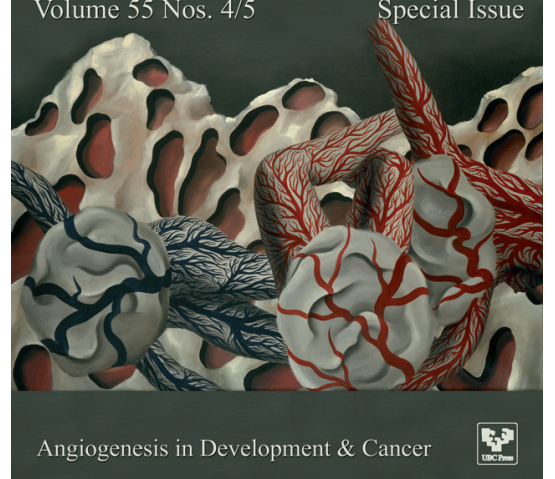

